\title{
RADIOCARBON DATES OF RIGA I
}

\author{
V S VEKSLER
}

All-Union Research Institute of Submarine Geology and Geophysics Riga, USSR

\section{INTRODUCTION}

The Riga Radiocarbon Laboratory began its serial measurements in 1971. Radiocarbon activity is measured by solution scintillation counters. Benzol, obtained by acetylene trimerization on vanadium pentoxide activated silicagel, is used as ${ }^{14} \mathrm{C}$ activity carrier. The dates refer to 1950 according to the 5568-year half-life of ${ }^{14} \mathrm{C}$. The statistical error is $1 \sigma$ (Veksler, Putans \& Savvaitov, 1971).

We present data here of samples from coastal regions of the USSR, which reflect their geologic-geomorphologic development (Veksler et al, 1975; Veksler, Putans \& Stelle, 1977; Veksler \& Prede, 1986).

\section{East Siberian Sea}

\section{Rautan Island series}

Samples were taken from coastal outcrop clearing in NW part of island. Subm by M E Voschilko.

Riga-97.

$10,980 \pm 540$

Birch branch fragment from $6 \mathrm{~m}$ depth.

Riga-98.

$9340 \pm 250$

Wood from 3.60 to $3.70 \mathrm{~m}$ depth.

Riga-99.

$8750 \pm 180$

Wood from 2.7 to $2.8 \mathrm{~m}$ depth.

Riga-100.

$8650 \pm 150$

Plant fragments from silty sand layer.

Riga-101.

$8280 \pm 200$

Peat from 1.8 to $1.9 \mathrm{~m}$ depth.

Riga-102.

$8210 \pm 120$

Wood from 0.30 to $0.40 \mathrm{~m}$ depth.

Riga-60.

$900 \pm 80$

Wood from coastal arch of modern stage sea, from mouth of Puchuveem R near Ust-Chaun. Subm by I G Veinberg.

Riga-70.

$4300 \pm 140$

Wood from $1.5 \mathrm{~m}$ depth in peat horizon foundation on bank of Puchuveem R. Subm by A P Valpeter. 
Riga-92.

$9490 \pm 130$

Wood from abrasion ledge composed of alluvial and coastal-marine sediments $1.7 \mathrm{~m}$ below earth layer at $40 \mathrm{~cm}$ from surface. Taken from $\mathrm{W}$ part of Chaun inlet, Nagleinynsky site.

\section{Ion Island series}

Riga-177.

$2100 \pm 180$

Peat rich in humus from second riverflat terrace of Uglovoye Lake, in SE part of island.

Riga-141.

$4680 \pm 150$

Weakly decomposed silty peat from upper part of thermokarst valley.

Riga-142.

$6770 \pm 160$

Weakly decomposed peat from lower part of thermokarst valley.

Riga-187.

$9270 \pm 120$

Herbaceous plants and peat fragments from seashore washout ledge in SE part of island.

Riga-184.

$10,450 \pm 210$

Herbaceous plants and peat fragments from washout ledge of lake in $\mathrm{S}$ part of island. Samples subm by F Kovalenko.

Riga-137a.

$9500 \pm 160$

Peat rich in humus from S part of Chaun inlet water area from 12.0 to $13.0 \mathrm{~cm}$ depth below modern sea level. Subm by F Ya Kovalenko.

Riga-108.

$11,340 \pm 120$

Wood fragments in peat laminae from $12 \mathrm{~m}$ depth below sea level. Subm by V A Vorobiev.

Riga-112.

$38,500 \pm 750$

Gray wood from $7 \mathrm{~m}$ depth below sea level. Subm by V A Vorobiev.

\section{Cape Kiberia series}

Samples Riga-273, -274, -285, -291 were taken from sea terrace. All samples subm by V P Bezrodnykh.

Riga-274.

$470 \pm 60$

Wood from terrace $5 \mathrm{~m}$ level sediments of sea terrace. Assumed date: Holocene $\left(Q_{\text {IV }}\right)$ or Karga interglacial.

Riga-273.

$8620 \pm 120$

Peat from thermokarst depression. Assumed date: $\mathrm{Q}_{\mathrm{IV}}$. 
Riga-290.

$38,740 \pm 360$

Peat taken from cane break sediments. Assumed date: $Q_{3}$.

Riga-291.

Peat from section of shelf zone loose cover. Assumed date: $\mathrm{Q}_{3}^{2-3}$.

Riga-286.

$\geqslant 31,810$

Peat from boring $16 \mathrm{~m}$ deep from seabed level in coastal part of cape.

Riga-287.

$8490 \pm 300$ $Q_{3}^{2}$.

Peat from section of loose cover of long strait shelf. Assumed date:

\section{Pechora Sea}

\section{Konstantinovka Section series}

Section is $1 \mathrm{~km} \mathrm{~W}$ of Konstantinovka on Pechora inlet. Thermokarst depression is stripped by coastal outcrop in section. Palynologic data are available. Samples subm by I G Veinberg.

Riga-234.

$4810 \pm 60$

Strongly decomposed peat from 0.5 to $0.6 \mathrm{~m}$ depth.

Riga-233.

$5030 \pm 80$

Weakly decomposed peat from 2.2 to $2.3 \mathrm{~m}$ depth.

Riga-232.

Peat with sand from 2.7 to $2.8 \mathrm{~m}$ depth.

Riga-231.

$7650 \pm 120$

Weakly decomposed peat from 2.8 to $2.9 \mathrm{~m}$ depth.

Riga-239.

$7640+100$

Weakly decomposed peat from 2.9 to $2.95 \mathrm{~m}$ depth.

$7680 \pm 100$

\section{Dresvyanka Section series}

Section is $6 \mathrm{~km}$ SW of Dresvyanka on Pechora inlet. Palynologic data are available. Samples were subm by I G Veinberg.

Riga-239a.

Srongly decomposed peat from 0.2 to $0.3 \mathrm{~m}$ depth.

Riga-238.

$4860 \pm 100$

Strongly decomposed peat from 0.5 to $0.6 \mathrm{~m}$ depth.

Riga-237.

$8540 \pm 100$

Moderately decomposed peat from 0.8 to $0.9 \mathrm{~m}$ depth. 
Riga-236.

$8640 \pm 80$

Weakly decomposed peat. Sample interval from 1.3 to $1.4 \mathrm{~m}$.

Riga-235.

$8790 \pm 90$

Weakly decomposed peat from 1.4 to $1.45 \mathrm{~m}$.

Riga-267.

$7840 \pm 240$

Wood from $1 \mathrm{~km}$ to the $\mathrm{N}$ of Farikha on the Pechora inlet. Subm by I G Veinberg.

Riga-294.

$5950 \pm 150$

Well-preserved brown peat from $0.8 \mathrm{~m}$ depth in inlet coastline of Pechora R near Kashen I., W coast of Pechora inlet. Subm by O G Epshtein.

Riga-298.

$4250 \pm 130$

Same as Riga-294, from $0.2 \mathrm{~m}$ above top.

Riga-293.

$4690 \pm 250$

Peat from Upper Quaternary moraine of Vastyansky kon' outcrop in Lower Pechora region. Subm by O G Epshtein.

Riga-277.

$5050 \pm 300$

Carbonized black peat 30 to $40 \mathrm{~cm}$ thick from Level I of marine terraces on $\mathrm{N}$ coast of Korovin inlet. Subm by O G Epshtein.

Riga-313.

$31,000 \pm 240$ tein.

Peat from E coast, $15 \mathrm{~km} \mathrm{~S} \mathrm{of} \mathrm{Kolokolova} \mathrm{inlet.} \mathrm{Subm} \mathrm{by} \mathrm{O} \mathrm{G} \mathrm{Epsh-}$

Riga-288.

$9250 \pm 310$

Small plant fragments from boring in W part of Yamal Peninsula. Subm by O G Okuneva.

\section{Western Coast of Kara Sea series}

\section{Riga-283.}

$7540 \pm 140$

Dark-brown peat lamina with herbaceous and shrub fragments. Sample was taken from upper part of outcrop, $7 \mathrm{~km} \mathrm{~S}$ of Tinteyakhi R.

Riga-279.

$\geqslant 10,590$

Peat, clayey in upper part, from outcrop $200 \mathrm{~m}$ from mouth of Navotalovskaya R.

\section{Riga-287.}

$\mathbf{3 5 , 4 0 0} \pm \mathbf{3 4 0}$

Sample from $2.5 \mathrm{~m}$ layer of thin laminae sequence of brown peat, 0.5 to $1 \mathrm{~cm}$ thick, and fine-grained gray sands. Sample taken from middle of outcrop $8.5 \mathrm{~km} \mathrm{~S}$ of Tinteyakhi R. 
Riga-280.

Same as Riga-284, slightly lower.

Riga-285.

Peat with clay and sand, from middle of sand horizon in sandy loam lamina in thermokarst scarp of marine terrace near mouth of Harasavei R.

Riga-281.

$\geqslant 31,520$

Washout peat laminae from loamy layers in outcrop $1100 \mathrm{~m} \mathrm{~N}$ of Cherny Bereg lighthouse.

Riga-299.

$35,970 \pm 370$

Wood fragment from clayey horizon in foundation of marine terrace section (II), $2250 \mathrm{~m} \mathrm{~N}$ of Harasavei lighthouse.

Riga-302.

$38,240 \pm 400$

Washout peak laminae from $1.75 \mathrm{~m}$ depth in outcrop on $\mathrm{W}$ coast of Yamal Peninsula $2 \mathrm{~km} \mathrm{~S}$ of Harasavei.

Riga-324.

$11,200 \pm 240$

Separate lenses of brown peat of $3.5 \mathrm{~m}$ depth in fine-grained sands in same loc as sample.

Riga-325.

$8840 \pm 120$

Peat from $1 \mathrm{~m}$ depth from brown lamina with large quantity of mineral components from outcrop on $\mathrm{W}$ coast of Yamal Peninsula, 2.6km N of Harasavei lighthouse. Samples subm by V G Miller and V M Gataulin.

\section{Coast of Kadym Lowland series}

Riga-253.

$9310 \pm 180$

Wood from bank of upper part of Bolshaya Kuropatochiya $\mathrm{R}$ from 7.5m depth. Assumed date: $\mathrm{Q}_{4}^{1}$.

Riga-250.

$9420 \pm 250$

Wood fragments from $5 \mathrm{~m}$ depth on bank of middle stream of Chuckochiya R. Assumed date: $Q_{4}^{1}$.

Riga-251.

$10,320 \pm 350$

Wood from 0.5m depth, on Cape Chuckochiya. Assumed date: $Q_{3}^{2}$.

Riga-259.

$21,670 \pm 370$

Wood from $5 \mathrm{~m}$ depth, on bank of lower stream of Konkovaya R. Assumed date: $Q_{2}-Q_{3}$.

Riga-262.

$13,850 \pm 450$

Plant fragments from 12.5 depth, on Cape Chuckochiya. Assumed date: $Q_{3}^{2}$. 
Riga-254.

Wood from $8.5 \mathrm{~m}$ depth from Antokhinskiy Yar on bank of Bolshoi Anny R. Assumed date: $Q_{2}-Q_{3}$.

Riga-252.

Wood from 5.5m depth on left bank of Kamenushki R. Assumed date: $\mathrm{Q}_{3}^{2-3}$. All samples subm by V G Miller.

\section{Kamchatka Coast}

\section{Mitoga River Basin series}

These samples were taken from peat bog of coast ledge $3 \mathrm{~km} \mathrm{~S}$ of Mitoga R mouth, 20km from Ust-Bolsheretsk. Peat bog dates to Holocene. Peat layer, $2.3 \mathrm{~m}$ thick is overlain by volcanic ash layer at $30 \mathrm{~cm}$ from top. Palynologic data are available. Samples subm by M E Voschilko. Table 1 shows stratigraphy of site. Samples are of peat from coastal sediments and marine borings. Sections were studied palynologically. Samples subm by R B Krapivner. Sea coastline $4.7 \mathrm{~km} \mathrm{~N}$ of Mitoga R mouth; peat, $2 \mathrm{~m}$ thick.

Riga-146.

$27,600 \pm 350$

Peat from upper section.

Riga-147.

$29,200 \pm 380$

Peat from middle part of section.

Riga-148a.

Peat from lower part of section.

Riga-148b.

Peat from lower part of section, $4.5 \mathrm{~km} \mathrm{~N}$ of Mitoga $\mathrm{R}$ mouth; peat, $0.4 \mathrm{~m}$ thick.

Riga-163.

$39,400 \pm 440$

Peat from upper part of section.

TABLE 1

Radiocarbon dates of Mitoga River peat

\begin{tabular}{rcr}
\hline Lab no. & $\begin{array}{c}\text { Sample interval } \\
(\mathrm{cm})\end{array}$ & $\begin{array}{c}\text { Date } \\
(\mathrm{yr} \mathrm{BP})\end{array}$ \\
\hline Riga-160 & $145-150$ & $4560 \pm 180$ \\
-161 & $150-160$ & $5750 \pm 150$ \\
-164 & $165-170$ & $6330 \pm 130$ \\
-183 & $170-175$ & $6680 \pm 180$ \\
-182 & $175-180$ & $7000 \pm 190$ \\
-179 & $190-195$ & $7500 \pm 170$ \\
-154 & $225-230$ & $10,200 \pm 280$ \\
\hline
\end{tabular}


Riga-169.

Peat from lower part of section $4.0 \mathrm{~km} \mathrm{~N}$ of Mitoga $\mathrm{R}$ mouth; peat, $2.7 \mathrm{~m}$ thick.

Riga-158.

$30,970 \pm 240$

Peat from upper part of section.

Riga-152.

$31,000 \pm 460$

Peat from middle part of section.

Riga-162.

$39,300 \pm 420$ thick.

Peat from lower part of section, $1 \mathrm{~km} \mathrm{~S}$ of Mitoga R. Peat is up to $1 \mathrm{~m}$

Riga-129.

$25,300 \pm 280$

Peat from upper part of section.

Riga-129a.

$\mathbf{3 4 , 8 0 0} \pm \mathbf{4 1 0}$

Humic acids of sample Riga-129. Outcrop is $3.1 \mathrm{~km} \mathrm{~S}$ of Mitoga R. Peat is 0.1 to $0.2 \mathrm{~m}$ thick.

Riga-132.

$37,100 \pm 300$

Brown peat lenses in silty sediments.

Riga-131.

$\geqslant 37,800$

Horizon of dense, strongly decomposed peat. Outcrop is $3 \mathrm{~km} \mathrm{~S}$ of Mitoga R. Peat is $1.5 \mathrm{~m}$ thick.

Riga-130.

$29,600 \pm 310$

Autochthonous peat taken from middle part of outcrop.

Riga-130a.

$\mathbf{3 5 , 7 0 0} \pm \mathbf{3 4 0}$

Humic acids of sample.

Riga-155.

$\mathbf{3 0 , 5 0 0} \pm 390$

Repeatedly taken sample from same locus as Riga-130. Outcrop on bank of Mitoga R, 8 to $10 \mathrm{~km}$ from its mouth.

Riga-149.

$31,200 \pm 410$

Buried peat from upper part of outcrop.

Riga-170.

$\geqslant 43,000$

Buried peat from power part of outcrop, on bank of Mitoga R, $100 \mathrm{~m}$ from its flooded mouth.

Riga-172.

$4660 \pm 130$

Modern peat from Utka outcrop. 
Riga-86.

$10,850 \pm 70$

Washout peat with small branches from 1.4 to $1.8 \mathrm{~m}$ depth.

Riga-89.

$\geqslant 39,000$

Washout laminated peat with small branches from 2.95 to $3.35 \mathrm{~m}$ depth.

Riga-85.

$11,400 \pm 70$

Washout dark-brown peat from upper part of outcrop with small branches from 1.5 to $2.3 \mathrm{~m}$ depth.

Riga-87.

$\geqslant 34,000$

Carbonized peat with no visible macroscopic plant fragments, from 3.05 to $3.35 \mathrm{~m}$ depth.

Riga-88.

$\geqslant 39,000$

Strongly decomposed grass-mossy peat with small branches from 5.1 to $6.6 \mathrm{~m}$ depth.

\section{Western coast of Sakhalin Bay}

\section{Petrovskaya Bar series}

Samples were taken from abrasion ledge clearing $150 \mathrm{~m}$ below distal end of Petrovskaya bar in clearing III. Samples subm by V Ya Stelle and M F Voschilko.

Riga-83.

$8280 \pm 130$

Sedgewood peat with small branches from 2.55 to $2.45 \mathrm{~m}$ depth.

Riga-90.

$6920 \pm 140$

Sedgewood peat from 2.35 to $2.30 \mathrm{~m}$ depth.

Riga-82.

$6630 \pm 100$

Sedgewood peat from 2.00 to $2.05 \mathrm{~m}$ depth.

Riga-84.

$5540 \pm 140$

Sedgewood peat from 1.90 to $1.85 \mathrm{~m}$ depth.

Riga-79.

$5140 \pm 100$

Hypnous peat from 1.45 to $1.40 \mathrm{~m}$ depth.

Riga-81.

$4570 \pm 130$

Hypnous-sphagnous peat from 1.15 to $1.10 \mathrm{~m}$ depth.

Riga-78.

$1340 \pm 110$

Sphagnous peat from 0.15 to $0.10 \mathrm{~m}$ depth. 
Riga-80.

$6560 \pm 120$

Small branches from lower part of horizon clearing II $50 \mathrm{~km} \mathrm{NW}$ of former section. Samples subm by S V Denisov.

Riga-95.

$8240 \pm 300$

Peat with wood fragments on contact between peat horizon $2 \mathrm{~m}$ thick and clay horizon.

Riga-94.

$19,950 \pm 450$

Wood branch piece from gravel sediments at 4.6 to $6.1 \mathrm{~m}$ depth.

Riga-93.

Wood from fine-grained and sand layer 4.9 to $5.1 \mathrm{~m}$ depth.

\section{Japan Sea Coastline}

\section{B, Tikhangou Bay series}

Riga-45.

$\mathbf{2 3 , 4 9 0} \pm \mathbf{4 4 0}$

Peat from 3.3 to $3.5 \mathrm{~m}$ depth of coast scarp on 5 to $6 \mathrm{~m}$ terrace of Bolotnaya R. Subm by R B Krapivner.

\section{Riga-41.}

$40,650 \pm 580$ pivner.

Peat from sea bed boring from Tikhangou site. Subm by R B Kra-

\section{Chukchi Sea}

Riga-278.

$10,040 \pm 370$

Peat laminae from 5.35 to $5.80 \mathrm{~m}$ depth of boring in center of Nehkan settlement, near Magadan.

\section{Riga-276.}

$95,160 \pm 430$

Lacustrine peat from lens foundation on upper part of 6 to $8 \mathrm{~m}$ terrace section on W bank of Neskyn-Pilkhin lagoon. Samples subm by O Bogdzevich.

\section{REFERENCES}

Veksler, V S and Prede, E I, 1986, Radiocarbon datings made at the laboratory of marine soil analytical studies of VMNPO "Soyuzmorinzhgeologiya": Comm Quaternary Studies Bull, Moscow, Nauka Pub, p 133-135 (in Russian).

Veksler, V S, Putans, B D and Savvaitov, A S, 1971, Modernization of the radiocarbon laboratory of VNIIMORGEO and some results of interlaboratory control of sample dating, in All-Union seminar astrophysical phenomena and radiocarbon, Proc: Vilnius, p 125-128

Veksler, V S, Putans, B D and Stelle, V Ya, 1977, Radiocarbon datings made at the laboratory of All-Union Research Institute of Submarine Geology and Geophysics: Comm Quaternary Studies Bull, Moscow, Nauka Pub, p 152-156 (in Russian).

Veksler, V S, Stelle, V Ya, Tsyganova, L V and Prede, E I, 1975, Radiocarbon datings made at the Laboratory of All-Union Research Institute of Submarine Geology and Geophysics: Comm Quarternary Studies Bull, Moscow, Nauka Pub, p 210-211 (in Russian). 